What are the general and what the ans. cultatory symptoms of valvular disense?

What are the consequences of valvular dişease?

What do you understand by pulmonary apoplexy?

Describe the appearance of the lungs after deatb from pulmonary apoplexy.

How would you distinguish the pulmonary apoplexy from hemoptysis?

What is pneumonitis?

What are its symptoms, general and auscultatory?

How would you treat it?

Who introduced large doses of tartar emetic for its treatment?

How did they administer it, and with what did they combine it?

In what doses would you administer it, and with what would you combine it?

With what wonld you combine it to lessen its irritating effect upon the mucons membrane of the stomach?

What is inflammation of the mucous membrane of the stomach called?

What are the symptoms of hypertrophy of the heart?

What are the symptoms of dilatation of the heart?

\section{Professor Connell.}

How are acids constituted ?

What is the composition of sulphuric acid?

What are oxyacids?

Enumerate a few of them.

What are hydracids?

Enumerate a few of them.

What is the constitution of hydrochloric acid?

Its old name.

What are the elements of hydrocyanic acid?

How is it prepared?

In a case of supposed poisoning by it, what tests would you apply to discover it?

To what has its smell bean compared?

What are the elements of cyanogen?

Is cyanogen a gas, fluid or solid?

What is the composition of the blood?

What are the elements of fibrine?

What is the constitution of serum?

What is the colouring matter of the blood called?

What is it supposed to be?

\section{Professor Lizars.}

What are the bones of the hip-joint?

What are its ligaments?

What nerve supplies it? hip.

Enumerate the muscles on the back of the

What is the origin of the gluteus medins?

Where is it inserted?

What are the vessels on the back of the hip?

What are the nerves?
$W$ here does the sciatic nerve come from?

Where does the internal pudic artery leave the pelvis?

Where does it re-enter it?

Of what artery is it a branch?

What vessels have you on the fore part of the thigh?

What nerves?

What is the relative situation of the artery to the symphysis pubis, and to the anterior superior spinous process of the ilium as it passes under Poupart's ligament?

What of the vein?

What of the nerve?

Of what artery is the profunda femoris a branch?

Is it given off to the onter or inner side of the artery?

What is that vein which opens into the outer side of the iliac vein just before it reaches Poupart's ligament?

How would you cut down and tie the femoral artery?

In performing this operation, what parts do you cat through?

Sappose you had amputated the thigh high up, and secondary hæmorrhage took place, what wonld you do?

Over what nerve would you apply a seton in disease of the hip.joint?

\section{Professor Robertson.}

What coat of the arteries is the most liable to dispase?

What are the diseases of arteries?

At what period of hife does ossitication of arteries usually occur?

What arteries are most subject to ossific disease?

What are the consequences of ossification of the arteries of the brain?

What do you understand by an aneurism?

What is meant by true aneurism?

What by false aneurism?

Which vessels are must subject to aneurism?

What operations are performed for the cure of aneurism?

What is aneurism by anastomosis?

What is venous aneurism?

The methods of cure for these swellings?

What is the most approved treatment for varicose veins?

\section{ST. COLUMB UNION TREACHERY. \\ Copy of a Letter addressed to the Editor of the "Cornwall Gazette." \\ "Penzance, Aug. 20, 1841.}

"SIr:-In your last week's paper appeared an advertisement containing the resolutions passed at a medical meeting held lately at Launceston, in which the conduct of Mr. Bullucke and myself, in reference to 
the St. Columb Union, has been very unfairly represented. The medical meeting to which I allude is the first half-yearly meeting of a very feto interested practitioners (residing principally within the St. Columb Union), who call themselves the 'Cornwall Medical Association.'

"The true representation of the affair is the following:-The St. Columb Union, in March or April last, offered its resident surgeons 2s. 6d. for each case of vaccination, a sum considerably beyond what is allowed by the Penzance and many other unions. But this remuneration the resident surgeons, in a body, refused to accept, and united to dictate terms to the guardians. The board, therefore, had no alternative but to advertise for medical relief, and Mr. Bullocke and myself offered our services. My tender was precisely the sara which had been pre. viously offered by the board to the resident surgeons; and those very sutgeons who are pleased to find fault with me for thus interfering with their attempt to coerce the guardians, actually tendered at the same time ten par cent. less than myself.

"I submit it, therefore, to the public to determine whether my cohduct was not far more worthy of my profession than that of the associated resident surgeons in the $S t$. Columb Union. I am, Sir, your obedient servant,

\section{"EDwin Edmonds."}

\section{To the Editor of The LANCET.}

SIR :-I beg to call your attention to the above true copy of a letter from $\mathrm{Mr}$. Ed. monds, and the reply of the St. Columb medical committee, in the accompanying number of the Cornwall Gazctle for August 27. I need hardly point out to you the mise. rable sophistry of Mr. Edmond's epistle, nor the expressions "dictate to and coerce the guardians." Moreover, it will be suffciently evident to the profession, that it was not until we had discovered that there were amongst our medical brethren renegades and deserters, who were prepared and anxious to betray us, and to hand over the key of our otherwise impregnable citadel to our oppo. nents, that we unwillingly consented to reduce our just demands. Having been attacked in front and flank and rear we are brought to bay, but we still hope that we shall present an impregnable phalanx, a square not easily brolken by the conjoint attacks of those who, as a public body only, are opposed to us, and of two individuals to whom might be well addressed the words, and I quote not irreverently-"It was not an enemy that did this, but thon, mine own familiar friend, in whom I trusted," \&c. \&c. I am, Sir, your obedient servant,

\section{J. H. NankivelL.}

St. Columb, Aug. 28, 1841.
** The letter in the Cornivall Gazette, of August 27, shows that as the Cornwall Me. dical Association enrols forty names, its members are not limited to practitioners in the St. Columb Union; but belong to every town in the county, and that its next meeting will be held at Truro, one having already been held at Bodmin, viz., in February last. The writers say that it is not true that in March or April last they were offered 2s. $6 \mathrm{~d}$. for each case of vaccina tion, but that $2 \mathrm{~s} .6 \mathrm{~d}$. was proposed to them in autumn 1840, and refused, and $3 \mathrm{~s}$. deemed barely sufficient. The guardians thereon postponed the ques. tion, and in the spring a tender was given in to them to take 185l. for the sixteen parishes. But this was refused, and $135 l$. offered to the medical gentlemen, and rejected; whereupon Messrs. Edmonds and Bullocke appeared as competitors. Upon that the board adnitted the justice of the tender, by assenting to give the $185 \mathrm{l}$. if the first parties would vaccinate at $1 \mathrm{s.} 6 \mathrm{~d}$. per case. Before, however, Mr. Bullocke's election, many too liberal deductions were offered by the surgeons, and all declined by the guardians. Then Mr. Edmonds tendered for $185 l$, offering to vaccinate at $1 \mathrm{s.} 6 \mathrm{~d}$. per case, and Mr. Bullocke consented to take 124l, for the general relief, and $\dot{2}_{\mathrm{s}}$, for vac. cination, per head; "and this offer, by a large majority of the board, was accepted: and thus a union, comprising sixteen parishes, a population of upwards of sixteen thousand, covering an area of one hundred and eleven miles, the extreme points of which are from eighteen to twenty miles apart, having three large towns in it, was, and still is, inirusted to the care of one man: a fact almost incredible, but nevertheless true." " And this tender was accepted," add the writers, " notwithstanding it was intimated to the poor-law commissioners and the guardians that be would have no assistance from either of us in any case which might arise."

There is no occasion to continue this controversy; Mr. Bnllocke and Mr. Edmonds may write till doomsday, cavilling and disputing ahout this little particular and that litile particular. Unless they can wipe from off the record the nonstrous fact which we have printed in italics, and disprove the allegation that one or both of then has brought to pass that startling iniquity to the poor, they had better be occupied in silently wearing their feet to the bone over the hundred and eleven miles, fulfilling conjointly as much of the union duty as is possible, than in sitting at home to attempt defences of indefensible proceedings. 
Noricic.-We are requested by Mr. Battley to state, that on the $30 \mathrm{th}$ of September he will exhibit, in the Great Hall of the Royal College of $\mathbf{F}$ hysicians, by permission of the President and Fellows, samples of drugs, and of certain original and active preparations, which he invites the members of the medical profession to inspect; and that he will continue his analysis of these drugs, during the autumnal and winter months, at the Laboratory attached to the Ophthalmic Hospital, Moorfields. We are requested to add, that the subjects of analysis will be regularly announced in this Journal.

\section{BOOKS RECEIVED.}

State of the Lincoln Lunatic Asylum, 1841. Lincoln: printed by $W$. and $B$. Brooke. Pp. 79.

Researches into the Physical History of Mankind, By James Cowles Prichard, M.D., F.R.S. Third Edition. Vol. 3, Part I. Containing Researches inlo the Ethrography of Europe. London: Sherwood and Co., 1841, 8vo. Pp. 507.

\section{TO CORRESPONDENTS.}

$M r$. George Butler, whose two replies, in relation to the operation performed upon him by Mr. Yearsley, appeared in The LA NoeT several weeks since, has sent to us this week a satisfactory explanation of what seemed to be irreconcilable in those answers. So long a time has elapsed between the publication of the replies and the transmission of Mr. Butler's present statement, that it will be sufficient to take the above notice of his explanation, without publishing the letter containing it.

G. L. Btard.-There are plenty of schools in the American towns, but all of them distinguished by the worst as well as the best features of the English system. No person goes to America from England for a medical education, unless the local attractions of the former country are rendered superior to the emigrant by his particular circumstances. Many American students come to Europe for instruction. The details which our correspondent wishes to have we cannot give.

To the Editor.-Sir: In TuE LanCET of Jan. 30th last appeared two letters, one from Messrs. Longman, the other from Dr. Cop. land, both having reference to the delay in the issue of the "Dictionary of Practical Medicine." In the latter document the writer, whose veracity and fair-dealing should run in right lines with his character as a physician, thus expresses himself-"I am now constantly engaged on the work, and shall have the $7 \mathrm{th}$ Part out in a few weeks." Seven months have elapsed since this announcement was made, and yet the 7th Part is unpublished: and it is the bounden duty, equally of the distinguished autior and his respectable publishers, to lay before the subscribers a candid statement of their real intentions with reference to this long-protracted work. Philalethes. Dublin, August 26.

Mr. Searle's communication has been re. ceived.

If $M r$. Yearsley really labours under any doubt as to the cause which induced our criticisms on his labours and declarations in the field of stammering, he may now learn what has long been quite obvious enough to every other man in the profession, namely, that his operations were denounced for their folly, their inutility, and their inhumanity, and his proceedings in relation to them for the character of quackery which eminently distinguished them. As to the reason for the "spireful animus" which he has invented at page 9 of his circular "To the Members of the Medical Profession," he is honestly assured that we there learned for the first time that any "new weekly medical publication" was in existence which could possibly awaken "feelings of rivalry" (!), or any other feelings, in The Lancet; or that Mr. Yearsley had ever " projected," or intended to execute, any "labours" in any periodical under the sun. If it be true that he is about to take the oar in a "new" journal, we pity the proprietor who admits him into the boat, which will only sink the sooner.

The letter of Mr. Bodington does not discuss the important point so briefly raised by "A Looker-on," npon a satisfactory basis. Moreover, the case of "A Looker-on" has not yet been stated, but only barely mentioned. Even, however, when it comes to be fully discussed, we shall not regard cases like those which $\mathrm{Mr}$. Bodington relates, as germane to the question. Mr. B. has overlooked the fact, that our correspondent refers to the advantages of a numerous society in uell-conducted public asylums. All of Mr. B.'s patients seem to have come from the most vicious quarters, and the worst managed company.

Scotus cannot attend, prescribe, and send medicines in medical cases, witliout being liable to prosecution. He might, by favour (not as a right), be admitted to examination for the licence, on certain conditions, the terms of which he could personally ask.

$A$ Subscriber.-We have not the Act at hand, but if onr correspondent procure it at the Queen's printers, he will probably ascertain that the clause declares that the medical visitor shall be a "legally-qualified medical practitioner." Probably the visitor in question came within the meaning of that term. The penal consequences of neglecting the directions of the law, are stated in the Act in their proper places. The asylum is a well-conducted establishment. 